DOI: $10.15593 / 2224-9389 / 2020.2 .17$

\author{
Yu.A. Melnik ${ }^{1}$, A.V. Kirova ${ }^{2}$ \\ ${ }^{1}$ Military University of the RF Ministry of Defense, \\ Moscow, Russian Federation \\ ${ }^{2}$ Dostoevsky Omsk State University, \\ Omsk, Russian Federation
}

Получена: 22.03.2020

Принята: 11.06 .2020

Опубликована: 04.08.2020

\title{
'THE FLYING SHIP' CARTOON FOR RUSSIAN AS A FOREIGN LANGUAGE CLASS AS A SOURCE OF PROBLEM-BASED SITUATIONS
}

The article describes methods of the work with Russian animated fairytale film 'The Flying Ship' at Russian as a foreign language class. The work is divided into three stages: pre-viewing, viewing and post-viewing ones. Concernment and involvement of students into active discussion at all stages are important factors of reaching education goals. Different methods providing real communication in learning environment such as a talk, a discussion, acting out dialogs, making stories or role games are suggested for use in the process of the work with the cartoon divided into problem-based logical parts. The work with any cartoon promotes students' activity, raises interest, and assures conditions for creative self-expression both for a teacher and a student as well as language immersion. During the communication within a simulated problem-based situation a foreigner participates in dialogs, learns to give full answers to questions, and articulates his or her ideas in Russian. The presented work lets foreign students reach a common understanding with representatives of a foreign culture and helps to create environment for learning the culture of their target language country, understanding peculiarities of national character and promoting adaptation of non-native speaker learners in Russian language environment.

Keywords: cultural linguistics, Russian as a foreign language, speaking skills development, problem-based situation, fairytale cartoon. 


\author{
Ю.А. Мельник ${ }^{1}$, А.В. Кирова ${ }^{2}$ \\ 1 Военный университет Министерства обороны \\ Российской Федерации, \\ Москва, Российская Федерация \\ 2 Омский государственный университет \\ им. Ф.М. Достоевского, \\ Омск, Российская Федерация
}

Received: 22.03.2020

Accepted: 11.06 .2020

Published: 04.08.2020

\title{
МУЛЬТФИЛЬМ «ЛЕТУЧИЙ КОРАБЛЬ» НА ЗАНЯТИИ ПО РУССКОМУ ЯЗЫКУ КАК ИНОСТРАННОМУ КАК ИСТОЧНИК ПРОБЛЕМНЫХ СИТУАЦИЙ
}

\begin{abstract}
В статье описывается методика работы с русским мультипликационным фильмом-сказкой «Летучий корабль» на занятии по русскому языку как иностранному. В работе выделяются три этапа: преддемонстрационный, демонстрационный и последемонстрационный. На всех этапах заинтересованность и вовлеченность обучающихся в активное обсуждение темы являются важным фактором для успешной реализации учебных задач. В процессе работы над мультфильмом, поделенном на проблемные смысловые отрезки, предлагается использовать различные приёмы, обеспечивающие реальное общение в учебной обстановке: беседа, дискуссия, составление диалогов и рассказов, ролевые игры. Работа с мультфильмом способствует повышению активности обучающихся и вызывает интерес, создает простор для творческого самовыражения как преподавателя, так и обучающегося с погружением в атмосферу реальной языковой коммуникации. В процессе общения в рамках смоделированной на занятии проблемной ситуации иностранец вступает в диалоги, учится давать развернутые ответы на вопросы, излагать свои мысли на русском языке. Данная работа позволяет иностранным студентам достигать взаимопонимания с представителями иноязычной культуры и помогает создать условия для изучения культуры страны изучаемого языка, познания особенностей национального характера и облегчает адаптацию инофонов в русской языковой среде.
\end{abstract}

Ключевые слова: лингвокультурология, русский язык как иностранный, развитие устной речи, проблемная ситуация, мультоильм-сказка.

\section{Introduction}

Modern studies devoted to Russian as a foreign language describe possibilities of video materials implementation quite detailed including animated ones which are possible to use at all levels of teaching $[1-3 ; 4 ; 5 ; 6 ; 7 ; 8 ; 9 ; 10 ; 11 ; 12]$.

In the works of A.N. Schukin an aspect of audio and video materials usage in Russian as a foreign language is fuller elaborated [13]. According to his opinion, such materials could be divided into "educational" that are made for educational purposes and "authentic" which are documentary, feature and animated films and records of TV programs. [ibid, p. 113]. To our mind, the work with animated film at Russian language classes has a great potential. Usually the work with films just at the class is obstructed by time limitation as teachers are to follow the curriculum. Students are often suggested to watch films at home but some part of linguistic information stays unclear while students watch it on their own. Fast speech tempo, 
different phonetic peculiarities, characters' accent, background noise and sounds obstruct correct perception and understanding of a movie. Attention of foreign students switches to glimpse pictures or general plot development. The work with an animated film often solves such problems as it duration is not long and lets watch a cartoon and perform necessary exercises right at the class under the guidance of an instructor. In the selection of materials for watching and further work one needs to take into account not only language level of students but also national features, gender of group members, preferences and interests of the class where a fairytale will be used.

\section{Russian fairytale cartoon as a source of intercultural communication}

Russian animated films are abundant and various in genres, still cartoons based on Russian fairytales deserve particular mention. A fairytale is one of the most beloved folk genres all over the world. A fairytale is understandable, clear and interesting for a student from any country as it reflects centuries-old traditions of a nation so, from the one hand, it is a material and a tool for language acquisition, from another, fictional and aesthetic phenomenon of culture. Folklore has always been one of the most important sources of language acquisition. It is the storage of cultural heritage of a nation which keeps track and transfers its philosophical, social and mental concepts about environment and humans by means of a language. The main function of a fairytale is "to be a tool of social and cross cultural communication, transmit channel of cultural knowledge and social experience" [7, p. 154]. Moreover, folklore texts are an important tool of building linguacultural competence that allows foreign students to reach a common understanding with people from another culture [14, p. 14]. Fairytales demonstrate characters' daily routine and national holidays, give evaluation to events and action of characters (good/bad, right/wrong) so it helps foreigners to find out and to understand conservative values, moral compasses and typical behavior models of the Russians. Such gradual introduction is an important condition for a sufficient perception of another culture values by a student who was raised in a different one.

Thus, a cartoon based on Russian fairytales has a unique culturological value. Moreover, the work with it helps a teacher and a student to develop creative skills. Also cartoons are used in teaching Russian as a foreign language for the purpose of nontranslatable vocabulary semantization as an extralinguistic situation created by audio and video has strong emotional impact on students and provides better vocabulary perception and remembrance. Besides, the work with animated films aids on creation of problem-based situations facilitates speaking skills development because "animated films are close to real human communication and help to teach students verbally appropriate behavior in everyday situations" [5, p. 175]. 


\section{Methodology of the work with cartoon 'The Flying Ship' (from teaching experience)}

An animated film is an exact situation, quite often a problem-based one which is familiar to almost all native speakers. The fairytale cartoon 'The flying ship' represents a wide range of problem-based situations. Drawing on the previously learnt vocabulary and new words, students learn to express their opinion, make proposals, ask for information, compare, agree or disagree with statements in the process of finding out, discussing and comparing such situations. Following E. Solovova, we stick to the algorithm of work with video materials: pre-viewing, viewing and postviewing stages. [15, p. 7].

Pre-viewing stage. At this stage it is practicable to introduce necessary vocabulary: a fairytale, happiness, to get married (for love, for money), Baba-Yaga, Vodyanoy, Tsar, Tsarevna. It is highly important to use pictures (multimedia presentation) of cartoon characters and provide cultural background information while introducing the vocabulary mentioned above.

Viewing stage. We suggest basing the learning activities on a problem approach. The cartoon is divided into logical parts containing a problem situation. After watching a cartoon segment and checking its understanding a teacher states the problem for discussion. Students express their opinion on the situation based on their value systems and concepts of their culture. Conversation is the main activity.

The generation gap problem. (0:00 - 1:00 segment. Zabava and her father). Questions: 1. Who are the characters of the fairytale? (Name, appearance, features of character). 2. What do they do? What are their jobs? 3. Are they poor or rich? 4. Do you like Polkan? Why? Is he good or bad? 5. What does the father want? What does the daughter want? What does Polkan want? 6. Does the daughter obey her father? Is it a problem or not? 7. Do children have a right to choose a husband/a wife for themselves or shall parents do that?

The problem: to marry for love or for money; love at first sight: myth or reality? (1:00 - 2:30 segment. An encounter of Zabava and the chimney sweep). Questions: 1. Does the princess want to get married? 2. What is more important for her: love or money? Why? 2. Does love at the first sight exist? 3. Do you believe in love at the first sight?

The problem: love between people from different social classes (from 2:30 4:40 segment. The start of love). Questions: 1.What is the name of a new character? 2. Describe him (appearance, character). 3. What is his mood? 4. What does he do? What's his job? 5. What is your opinion: is he rich or poor? Is there a problem in it? 6. What did Ivan bring to the princess? 7. Does she like his words? 8. What feelings are between them? 9. What did Ivan decide to do to make Zabava's father let them get married? 10. What did Tsar tell Polkan and what did he reply? Why did he reply like that? 
The problem of pursuit of happiness: 'What is happiness and what constitutes mine?' (4:40 - 8:12 segment. The song about happiness). Questions: 1 . What makes the princess happy? What does she dream of? 2. What does the father-king dream of? 3. What does Polkan dream of? 4. Can you guess what does 'from rags to riches' mean? 5. What does the chimney sweep dream of? What makes him happy?

The problem of loneliness, having/lack of free choice (8:12 - 9:50 segment. The song by Vodyanoy). Questions: 1. Who is it? Describe him. 2. What does he dream of? 3. Is it difficult to be alone or Vodyanoy is satisfied with his life? 4. Does he help to Ivan? How? Why?

The problem of hard work (8:12 - 9:50 segment. The building of the ship). Questions: 1. Did Ivan build the flying ship? 2. Why couldn't he build the flying ship? 3. Why couldn't Polkan build the flying ship? 4. Russians say about people like Ivan that 'he has the magic touch'. What do you think it means?

The problem of cowardice and bravery, strength and weakness. Questions: 1. Why did Tsar give the crown to Polkan? 2. Is he brave or coward? Strong or weak? 3. Is Ivan strong or weak? Where does his strength lie? 4. Why did Ivan and Zabava fly away instead of staying in the palace?

Post-viewing stage.

The teacher defines the range of the mentioned issues (shows on multimedia presentation schematically): the problem of loneliness, generation gap; love or money; is love at first sight possible; marriage for love or for money; what is happiness? Students express their opinion, make up a conclusion. Home task could be to write an essay on one of the mentioned topics or to come up with the continuation of the cartoon ("They flew away together. What happened next?"). In multinational study groups it is interesting to perform a role game "What about you?" Students have to perform a dialog between the father and the daughter, Zabava and the chimney sweep, Polkan and Zabava, based on cultural and behavioral attitudes approved in their native countries.

Undoubtedly, the given range of problem-based situations is approximate and could be widen/narrowed/altered depending on needs and goals of each student group. The authors have piloted the presented material both in mono- and multinational groups and can emphasize that the work with the cartoon 'The Flying ship' elicits not only an enthusiastic feedback from students (nobody stays indifferent), but also "involves students into cognitive activity related with drawing a meaning" [16, p. 19].

\section{Conclusion}

Thus, Russian fairytale cartoons are a comprehensive educational source for teaching foreign students. They help to handle a lot of teaching and learning tasks. 
The work with the fairytale cartoon 'The flying ship' promotes the creation of problem-based situations at classes, which lets activate speaking skills, hence develop linguistic and extralinguistic competences in foreign students. A cartoon lets a foreigner 'dive' into Russian national culture, understand basic values, discover national character peculiarities that all help in adaptation to Russian extralinguistic language environment.

\section{Список литературы}

1. Абдрахманова И. Э. Совершенствование русской речи иностранных студентов на основе восприятия российской аудиовизуальной культуры: автореф. дис. ... д-ра пед. наук. - М., 2010. - 46 с.

2. Абдрахманова И.Э. Методика работы над словом на аудиовизуальных занятиях русским языком как иностранным // Вестник РУДН. Сер. Русский и иностранные языки и методика их преподавания. - 2009. - № 4. - С. 93-99.

3. Абдрахманова И.Э. Работа над аудиовизуальным текстом сказки Аксакова «Аленький цветочек» в иностранной аудитории // Художественный текст и языковая личность: материалы IV Всерос. науч. конф. (27-28 октября 2005 г.) / под ред. проф. Н.С. Болотновой. - Томск: Изд-во ЦНТИ, 2005. - С. 316-321.

4. Барышникова Е.Н., Денисова А.А. Чебурашка и его друзья: пос. по разв. речи с использованием мультфильмов. - М.: Изд-во РУДН, 2006. - 71 с.

5. Кривонос Е.А. Использование мультипликационных фильмов на уроке РКИ // Международные отношения: история, теория, практика: материалы I науч.-практ. конф. молодых ученых фак. междунар. отношений (БГУ, Минск, 4 февр. 2010 г.). Минск: Изд. центр БГУ, 2010. - 189 с.

6. Курлова И.В. Использование мультипликационных, учебных и художественных фильмов на уроке русского языка // Сб. науч.-информац. материалов по итогам проведения мероприятий, посв. празднованию Дня рус. яз. в Болгарии, Сербии, Словении, Греции. - М: Изд-во Ин-та рус. яз. и культуры МГУ им. М.В. Ломоносова, 2013. - С. 110-114.

7. Подручная Л.Ю. Интерпретация пространства и времени волшебной сказки в процессе обучения русскому как иностранному // Известия КГТУ. - 2007. - № 12. C. $151-156$.

8. Подшивалова Е.А. Представление русских глаголов движения через мультфильмы (на примере сказки «Гуси-лебеди») // Иноязычное образование в современном мире. - Ч. 2. - М.: Правда-пресс, 2012. - С. 124-129.

9. Ряшенцев В.А., Назаренко Н.А. Тайна третьей планеты / Университет Ёнсэ, Институт изучения иностранных языков. - Сеул, 2000. - 35 с.

10. Салахова А.Р. Лингводидактический потенциал советской анимации на уроках русского языка как иностранного // Филология и культура. - 2016. - № 1(43). C. 314-319.

11. Смелова Д.А., Уша Т.Ю. Мультипликационный фильм «Трое из Простоквашино»: метод. разработка к аудиовизуальному курсу: для студ.-иностранцев и преп. РКИ. - СПб.: Сударыня, 2005. - 37 с. 
12. Усатюк Н.Б., Мельник Ю.А. Использование фольклора на занятиях по русскому языку как иностранному (РКИ) // Научное образование Саяно-Алтая. - 2017. № 2 (18), - С. 75-78.

13. Щукин А.Н. Методика использования аудиовизуальных средств (при обучении русскому языку как иностранному в вузе). - М.: Русский язык, 1981. - 128 с.

14. Игошина О.А. Лингвокультурологический анализ фольклорного текста при обучении русскому языку немецкоязычных студентов: дис. ... канд. пед. наук. - СПб., 2003. $-210 \mathrm{c}$.

15. Соловова Е.Н. Методика обучения иностранным языкам: базовый курс: учеб. пособие. - М.: Просвещение, 2008. - 238 с.

16. Трыгуб И.С. Лингвометодический потенциал народных сказок в обучении русскому языку как иностранному младших школьников: автореф. дис. ... канд. пед. наук. - М., 2006. - 48 с.

\section{References}

1. Abdrakhmanova I.E. Sovershenstvovanie russkoi rechi inostrannykh studentov na osnove vospriiatiia rossiiskoi audiovizual'noi kul'tury [Improving Russian speech of foreign students based on perception of Russian audio and visual culture]. Ph.D. thesis, Moscow, 2010, 46 p.

2. Abdrakhmanova I.E. Metodika raboty nad slovom na audiovizual'nykh zaniatiiakh russkim iazykom kak inostrannym [Methods of work on Russian word at audiovisual classes in Russian as a foreign language]. Vestnik RUDN: seriia: russkii $i$ inostrannye iazyki $i$ metodika ikh prepodavaniia, 2009, no. 4, pp. 93-99.

3. Abdrakhmanova I.E. Rabota nad audiovizual'nym tekstom skazki Aksakova "Alen'kii tsvetochek" v inostrannoi auditorii' [The work on audiovisual fairytale text of 'The Scarlet Flower' with foreign students]. Khudozhestvennyi tekst i iazykovaia lichnost'. Proc. 4th All-Rus. Sci. Conf. (October 27-28, 2005). Tomsk, 2005, pp. 316-321.

4. Baryshnikova E.N. Cheburashka i ego druz'ia [Cheburashka and his friends]. Textbook. Moscow, RUDN, 2006, 71 p.

5. Krivonos E.A. Ispol'zovanie mul'tiplikatsionnykh fil'mov na uroke RKI [The use of multimedia films at Russian as a foreign language classes]. Mezhdunarodnye otnosheniia: istoriia, teoriia, praktika. Proc. 1st Sci-Pract. Conf. of young scientists of international relationships department (February 4, 2010). Minsk, Minsk State University, 2010, 189 p.

6. Kurlova I.V. Ispol'zovanie mul'tiplikatsionnykh, uchebnykh i khudozhe-stvennykh fil'mov na uroke russkogo iazyka [The use of animated educational and fictional films at Russian language lesson]. Proc. Russian language Day in Bulgaria, Serbia, Slovenia and Greece. Moscow, Institute of Russian Language and Culture, Lomonosov Moscow State University, 2013, p. 110-114.

7. Podruchnaia L.Iu. Interpretatsiia prostranstva i vremeni volshebnoi skazki v protsesse obucheniia russkomu kak inostrannomu [Interpretation of space and time in a magic fairytale in the process of teaching Russian as a foreign language]. Izvestiia KGTU, Kaliningrad, 2007, no 12, pp. 151-156.

8. Podshivalova E.A. Predstavlenie russkikh glagolov dvizheniia cherez mul'tfil'my (na primere skazki "Gusi-lebedi”) [Representation of Russian verbs of movement through 
cartoons (by the example of fairytale 'Gusi-lebedi']. Inoiazychnoe obrazovanie v sovremennom mire. Part 2. Moscow, Pravda-press, 2012, pp. 124-129.

9. Riashentsev V.A., Nazarenko N.A. Taina tret'ei planety [Secrets of the third planet]. Seoul, Republic of Korea, Yonsei University, 2000. 35 p.

10. Salakhova A.R. Lingvodidakticheskii potentsial sovetskoi animatsii na urokakh russkogo iazyka kak inostrannogo [The didactic capacity of soviet animated films in Russian language teaching]. Filologiia i kul'tura, 2016, no. 1(43), pp. 314-319.

11. Smelova D.A., Usha T.Iu. Mul'tiplikatsionnyi fil'm “Troe iz Prostokvashino" [Animated film 'Troe iz Prostokvashino']. Guide for audiovisual course for students-foreigners and teachers of Russian as a foreign language. Saint-Petersburg, Sudarynia, 2005, 37 p.

12. Usatiuk N.B., Mel'nik Iu.A. Ispol'zovanie fol'klora na zaniatiiakh po russkomu iazyku kak inostrannomu (RKI) [The use of folklore at Russian as a foreign language lessons]. Nauchnoe obrazovanie Saiano-Altaia, no. 2 (18), 2017, pp. 75-78.

13. Shchukin A.N. Metodika ispol'zovaniia audiovizual'nykh sredstv (pri obuchenii russkomu iazyku kak inostrannomu v vuze) [Methods of using audiovisual means in teaching Russian as a foreign language]. Moscow, Russkii iazyk, 1981, 128 p.

14. Igoshina O.A. Lingvokul'turologicheskii analiz fol'klornogo teksta pri obuchenii russkomu iazyku nemetskoiazychnykh studentov [Linguocultural analysis of folklore text in teaching Russian language to German-speaking students]. Ph.D. thesis, Saint-Petersburg, 2003, 210 p.

15. Solovova E.N. Metodika obucheniia inostrannym iazykam: bazovyi kurs [Methods of teaching foreign language: Basic course]. Moscow, Prosveshchenie, 2008, 238 p.

16. Trygub I.S. Lingvometodicheskii potentsial narodnykh skazok v obuchenii russkomu iazyku kak inostrannomu mladshikh shkol'nikov [Linguo-didactic potency of folk tales in teaching Russian as a foreign language to elementary school children]. Ph.D. thesis, Moscow, 2006, 48 p. 


\section{Сведения об авторах}

\section{МЕЛЬНИК Юлия Александровна}

e-mail: uliya0783@mail.ru

Преподаватель кафедры русского языка, Военный университет Министерства обороны Российской Федерации (Москва, Российская Федерация)

\section{КИРОВА Анастасия Владимировна}

e-mail: anastasia.kirova@gmail.com

Старший преподаватель кафедры иностранных языков, Омский государственный университет им. Ф.М. Достоевского (Омск, Российская Федерация)
About the authors

\section{Yuliya A. MELNIK}

e-mail: uliya0783@mail.ru

Lecturer of the Chair of Russian Language, Military University of the RF Ministry of Defense (Moscow, Russian Federation)

\section{Anastasiya V. KIROVA}

e-mail: anastasia.kirova@gmail.com

Senior Lecturer, Chair of Foreign Languages, Dostoevsky Omsk State University (Omsk, Russian Federation) 